\title{
Biosimilars: an overview
}

This article was published in the following Dove Press journal:

Biosimilars

I4 March 20II

Number of times this article has been viewed

\section{Bhupinder Singh Sekhon Vikrant Saluja}

Institute of Pharmacy, PCTE Group of Institutes, Near Baddowal Cantt. (Ludhiana), India
Correspondence: Bhupinder Singh Sekhon Institute of Pharmacy, PCTE Group of Institutes, Near Baddowal Cantt. (Ludhiana), I4202I, India

Tel +9l-16I-2888550

Email sekhon224@yahoo.com
Abstract: "Biologics", considered one of the fastest growing sectors of the pharmaceutical industry, has introduced many new treatments to life-threatening and rare illnesses. The first generation of biopharmaceutical products manufactured using recombinant technologies was launched in the 1980s, and they are now on the way to patent expiration. As a result, researchbased and generic pharmaceutical companies alike are pursuing the opportunity to develop "generic" substitutes for original biologics, herein referred to as biosimilars. However, the process of introducing a biosimilar to an innovator product is far more complex than the relatively straightforward process of introducing a generic equivalent to an innovator product based on a new chemical entity. Biologics are produced by cells in culture or whole organisms, which are inherently more variable than chemical synthesis methods. Therefore, unlike generic pharmaceuticals, it is impossible to generate the same or identical copy of an innovator product. In this way, biosimilars are "similar but not the same" or in other words biosimilars are "the twin but not the clone" to the original biologic innovator product. Therefore the field of biosimilars presents several important challenges, including i) verification of the similarity, ii) the interchangeability of biosimilars and innovator products, iii) the possible need for unique naming to differentiate the various biopharmaceutical products, iv) regulatory framework, v) commercial opportunities as well as guidelines to assist manufacturers in product development, vi) intellectual property rights, and vii) public safety.

Keywords: biosimilars, biologics, innovator product, pharmacovigilance, regulatory

\section{Introduction}

"Biologics" represent one of the fastest growing segments of the pharmaceutical industry. They refer broadly to substances produced by living cells using biotechnology (ie, recombinant DNA technology, controlled gene expression, or antibody technologies), which have introduced many new treatments to life-threatening and rare illnesses such as cancer, diabetes, anemia, rheumatoid arthritis and multiple sclerosis. They involve a wide range of substances, including recombinant hormones, growth factors, blood products, monoclonal antibody-based products, recombinant vaccines, and advanced technology products (gene and cell therapy biological products). ${ }^{1}$ The global biologic industry has come a long way since its first drug Humulin earned US Food and Drug Administration (FDA) approval in 1982. ${ }^{2}$ Biologic sales now account for about US\$92 billion and are expected to worth more than US\$167 billion by $2015 .^{3}$ By 2014, biologics are expected to occupy six of the top ten positions in the pharmaceutical industry. ${ }^{4}$ The ever-increasing pressure on healthcare budgets globally, requires cost savings analogous to those arising from the generic versions of original 
innovator product..$^{5-9}$ The pharma market is now open for generic versions of biologics, referred to as "biosimilars" in Europe, "follow-on pharmaceuticals" in the US and Japan, "subsequent entry biologics" in Canada, "biocomparables" in Mexico and, in this manuscript, "biosimilars". These terms arise from the loss of patent protection by many firstgeneration innovator products in the last few years, and the expectation that a few more will suffer the same fate in the next few years. However, unlike the relatively uncomplicated process of introducing a generic equivalent of an original chemical based drug, the process of introducing a biosimilar to an innovator product is far more complex. This is apparent as i) biologics generally exhibit high molecular complexity ii) biologics are produced by cells in culture or whole organisms, and iii) major changes in the product can occur due to very minor changes in the process. ${ }^{10,11}$

Various complexities associated with approval of a biosimilar include: i) evidence of integrity and consistency of the manufacturing process, ii) conformance of manufacturing standards to applicable regulations, iii) demonstration of product consistency with appropriate innovator product or comparators using assays that should be relevant and most of all standardized, so that several biosimilars of the same biologic can be comparable, including comparative pharmacokinetic and pharmacodynamic data and the extent of clinical data, and iv) experience with the approved product. ${ }^{12}$ Further, issues like post-translation modification and immunogenicity are the key concern related to approval of biosimilar products. ${ }^{13}$ Scientists are of the opinion that the use of biosimilars is an opportunity for us to use cutting-edge technology to solve health problems and guide clinical processes.

\section{Biologics versus small-molecule drugs}

Significant differences exist between biologics and typical small-molecule drugs basically because of difference in origin (Tables 1 and 2). Chemical methods are generally used to produce small-molecule drugs whereas biological products are synthesized usually by cells or living organisms. ${ }^{14}$ This difference in origin leads to difference in structure, composition, manufacturing methods and equipment, intellectual property, formulation, handling, dosing, regulation, and marketing.

Compared with synthetic small molecules, biologics are 100 to 1000 times larger in size, having several hundred amino acids (average molecular weight of 150 per amino acid), biochemically joined together in a defined sequence by peptide bonds to form a polypeptide. In contrast, conventional drugs are far smaller, ie, molecular weight $<1000$, self-contained, organic molecules that are, usually, chemically synthesized. ${ }^{15}$ Further, the bigger the molecule, the greater the number of atoms that make up its structure and the greater its complexity. Thus, structurally, biologics are more complex than low molecular weight drugs, consisting of primary (amino acid sequence) and secondary ( $\alpha$-helix and

Table I Difference between innovator products and small-molecule drugs

\begin{tabular}{|c|c|c|}
\hline & Small-molecule drugs & Biologic drugs \\
\hline Product-related & - Produced by chemical synthesis & - Biotechnologically produced by host cell lines \\
\hline \multirow[t]{12}{*}{ differences } & - Low molecular weight & - High molecular weight \\
\hline & - Well-defined physiochemical properties & - Complex physiochemical properties \\
\hline & - Stable & - Sensitive to heat and shear (aggregation) \\
\hline & $\begin{array}{l}\text { - Single entity, high chemical purity, purity standards well } \\
\text { established }\end{array}$ & $\begin{array}{l}\text { - Heterogeneous mixture, broad specification which may } \\
\text { change during development, difficult to standardize }\end{array}$ \\
\hline & - Administered through different routes of administration & - Usually administered parenterally \\
\hline & - Rapidly enters systemic circulation through blood capillaries & - Larger molecule primarily reach circulation via lymphatic \\
\hline & - Distribution to any combination of organ/tissue & system, subject to proteolysis during interstitial and \\
\hline & - Often specific toxicity & lymphatic transit \\
\hline & - Often non-antigenic & - Distribution usually limited to plasma and/or \\
\hline & & extracellular fluid \\
\hline & & - Mostly receptor mediated toxicity \\
\hline & & - Usually antigenic \\
\hline Manufacturing & - Completely characterized by analytical methods & - Difficult to characterize \\
\hline \multirow[t]{3}{*}{ differences } & - Easy to purify & - Lengthy and complex purification process \\
\hline & $\begin{array}{l}\text { - Contamination can be generally avoided, is easily detectable } \\
\text { and removable }\end{array}$ & $\begin{array}{l}\text { - High possibility of contamination, detection is harder and } \\
\text { removal is often impossible }\end{array}$ \\
\hline & $\begin{array}{l}\text { - Not affected by slight changes in production process and } \\
\text { environment }\end{array}$ & $\begin{array}{l}\text { - Highly susceptible to slight changes in production process } \\
\text { and environment }\end{array}$ \\
\hline
\end{tabular}


Table 2 Comparison of generic, biosimilar, and innovator products

\begin{tabular}{|c|c|c|c|}
\hline Process & Biologic & Biosimilar & Generic \\
\hline \multirow[t]{3}{*}{ Manufacturing } & $\begin{array}{l}\text { Produced by biological process in } \\
\text { host cell lines }\end{array}$ & $\begin{array}{l}\text { Produced by biological process in } \\
\text { host cell lines }\end{array}$ & Produced by using chemical synthesis \\
\hline & $\begin{array}{l}\text { Sensitive to production process } \\
\text { changes - expensive and specialized } \\
\text { production facilities }\end{array}$ & $\begin{array}{l}\text { Sensitive to production process } \\
\text { changes - expensive and specialized } \\
\text { production facilities }\end{array}$ & $\begin{array}{l}\text { Less sensitive to production process } \\
\text { changes }\end{array}$ \\
\hline & Reproducibility difficult to establish & Reproducibility difficult to establish & Reproducibility easy to establish \\
\hline \multirow[t]{2}{*}{$\begin{array}{l}\text { Clinical } \\
\text { development }\end{array}$} & $\begin{array}{l}\text { Extensive clinical studies, including } \\
\text { Phase I-III }\end{array}$ & $\begin{array}{l}\text { Extensive clinical studies, including } \\
\text { Phase I-III }\end{array}$ & Often only Phase I studies \\
\hline & $\begin{array}{l}\text { Pharmacovigilance and periodic safety } \\
\text { updates needed }\end{array}$ & $\begin{array}{l}\text { Pharmacovigilance and periodic safety } \\
\text { updates needed }\end{array}$ & Short timeline for approval \\
\hline \multirow[t]{4}{*}{ Regulation } & Needs to demonstrate "comparability" & Needs to demonstrate "similarity" & Needs to show bioequivalence \\
\hline & Regulatory pathway defined by & Regulatory pathway defined by & Abbreviated registration procedures \\
\hline & Europe (EMEA) & Europe (EMEA) & in Europe and US \\
\hline & $\begin{array}{l}\text { Currently no automatic substitution } \\
\text { intended }\end{array}$ & No automatic substitution allowed & Automatic substitution allowed \\
\hline
\end{tabular}

Abbreviation: EMEA, European Medicines Agency.

$\beta$-pleated sheet) structures, which are folded into complicated 3D tertiary structures. ${ }^{16}$ In some biopharmaceuticals, stable associations of tertiary structures of individual proteins form a quaternary structure. After synthesis, these structures are often further modified by post-translational modifications such as glycosylation or sialylation, which may be crucial for biological activity. ${ }^{17}$ Furthermore, due to larger size and structural complexity, the characterization of a biopharmaceutical presents an enormous challenge.

Despite the availability of a wide range of novel techniques for characterizing structure and physicochemical properties, the inherent complexity of biopharmaceuticals means that the picture will be incomplete even if all available methods are used. Typically, it is impossible to fully define these characteristics for any given product, and they may vary with different manufacturing processes. ${ }^{18}$ In contrast, traditional small-molecule drugs have a well-defined and stable chemical structure, which can be completely characterised by analytical methods. ${ }^{19}$ Moreover, biopharmaceutical production methods are also more complex, involving several steps and subject to variation affecting the biological and clinical properties of the drug (Figure 1). ${ }^{20}$ In short, the sensitivity of biological production to manufacturing conditions far exceeds that of chemical production. ${ }^{21}$ Further, pre-clinical and clinical development of biologics are a major issue with manufacturing costs easily reaching 100 -fold of those of small molecules. ${ }^{22-25}$ Another important difference between biopharmaceuticals and low molecular weight drugs is their immunogenicity. Nearly all therapeutic proteins induce antibodies, irrespective of whether these proteins are (partly) non-human or completely human homologs. They may decrease efficacy or may induce severe side effects by neutralizing endogenous factors. ${ }^{26}$ Thus complex and often expensive biologics raise critical commercial challenges compared with small-molecule drugs - the most important of which pertains to developing a viable pricing, distribution and reimbursement model that is intrinsically geared to the special characteristics of biologics and the expectations of a diverse customer population. ${ }^{27}$ Because biologics now comprise about a third of the medicines approved, understanding whether their biological differences translate into commercial and economic differences is important for understanding health care economics, effective innovation incentives, and anticipated public health improvements. Because of innate biology, production, and dosing regimes, biologics often differ from small molecule medicines in their product development, regulatory approval, distribution, and commercial paths. Thus, although they have the same medical goal - to treat disease - small-molecule and biologics therapeutics differ substantially in ways that might affect innovation, safety, costs, clinical adoption, patient access, and pricing. ${ }^{28}$

\section{Regulation aspects of biosimilars}

A generic drug is a much less expensive copy of an innovator drug product. Generics can be produced when the patent on a drug has expired, for drugs which have never held patent, in countries where a patent(s) is/are not in force, and where the generic companies certify that the branded companies' patents are either invalid, unenforceable, or will not be infringed. Generic drug manufacturers apply for marketing approval of generic drugs under the Abbreviated New Drug Application (ANDA) pathway established by FDA. Moreover, generic drug applications are termed "abbreviated" because they are generally not required to 


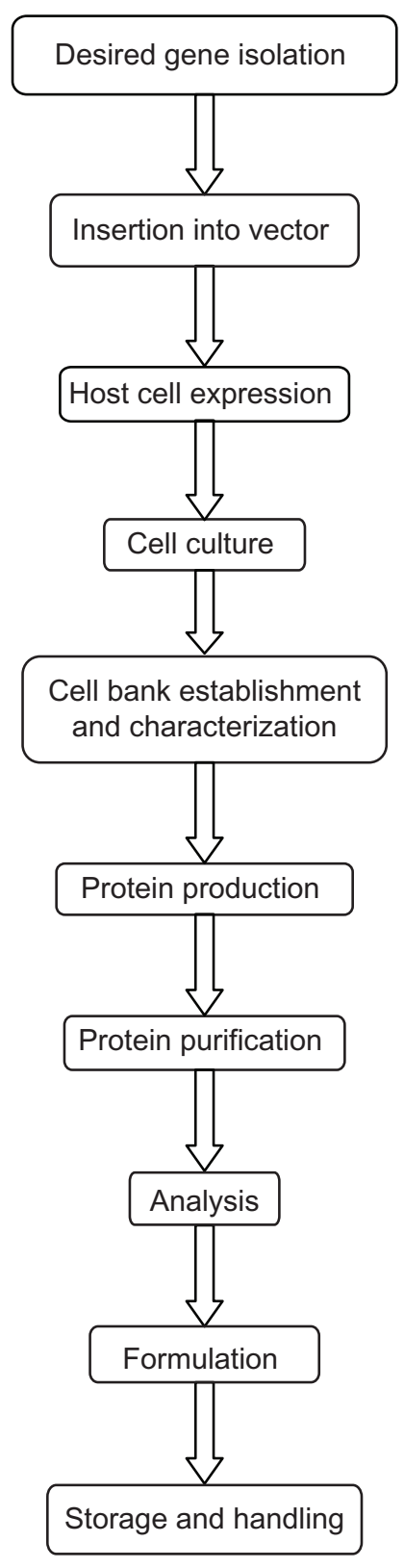

Figure I Typical steps in manufacturing of a biologic product.

include preclinical and clinical data to establish safety and effectiveness. The generic manufacturer needs to demonstrate only pharmaceutical equivalence and bioequivalence between the generic and innovator products, in order to gain approval for their generic product.

This approach cannot be extrapolated to biosimilars, however, because the active substance of a biopharmaceutical is a collection of large protein isoforms and not a single molecular entity, as is generally true for conventional smallmolecule drugs. Thus the active substances in two products are highly unlikely to be identical and, therefore, unlike generics, biosimilars are only similar and not identical to the innovator products. These differences imply that biosimilars should not be approved and regulated in the same way as conventional generic drugs.

The regulatory pathway for approval of biosimilars is more complex than for the generic innovator product because the design of a scientifically valid study to demonstrate the similarity of a highly process-dependent product is not easy. Further, the analytical tests currently available are not sophisticated enough to detect the slight but important structural differences between innovator and biosimilar products. Modest differences may have clinical implications and pose a significant risk to patient safety. Therefore, it is considered necessary that biosimilars must be assessed for clinical efficacy and safety by valid preclinical and clinical studies before marketing approval. ${ }^{19,29-31}$

The European Medicines Agency (EMEA) has moved ahead of the rest of the world in this direction, and issued a number of general guidelines that detail the requirements for market approval (Table 3). ${ }^{32-41}$ In addition to these guidelines, product-class-specific guidelines have been issued for the development of biosimilars based on recombinant erythropoietin, somatotropin, human granulocyte colony-stimulating factor, human insulin, recombinant IFN-a, and low molecular weight heparins (Table 3). Generally, the approval process varies according to the products, because significant differences exist between them, and allow products to be assessed on a case by case basis. ${ }^{42}$

In the US, after the approval of biosimilar Omnitrope in 2006, the FDA stated that no other biosimilar will be approved until a specific regulation has been issued..$^{43}$ The Pathway for Biosimilars Act of 2009 and the Patient Protection and Affordable Care Act of 2010 have provided greater clarity, and a reasonably clear mandate from the US Congress for the FDA to act more openly and decisively on an abbreviated approval pathway for biological products. However, in Canada, the first Subsequent Entry Biologic (SEB) Omnitrope ${ }^{\mathrm{TM}}$ was approved on April 20, 2009. Recently, Health Canada published its finalized guidance document for the approval of SEBs with the intention that this document would serve as an administrative aid to guide SEB decision-making. ${ }^{44}$

In fact, the regulations covering the market approval of biosimilars are still evolving around the world. With progress in the US, Australia, Canada, Japan, Turkey, and other countries around the world already armed with a regulatory framework for biosimilar medicines, there is a need to reach global agreement on criteria and guidelines for such products. This objective is inspired by ethical and scientific 
Table 3 Overview of European Medicines Agency biosimilar guidelines

\begin{tabular}{|c|c|}
\hline \multicolumn{2}{|c|}{ Applicable to all biosimilars } \\
\hline Overarching & Guideline on similar biological medicinal products ${ }^{32}$ \\
\hline Quality & $\begin{array}{l}\text { Guideline on similar biological medicinal products containing biotechnology-derived proteins as active } \\
\text { substance: quality issues }\end{array}$ \\
\hline Non-clinical and clinical & $\begin{array}{l}\text { Guideline on similar biological medicinal products containing biotechnology-derived proteins as active } \\
\text { substance: non-clinical and clinical issues }{ }^{34}\end{array}$ \\
\hline Immunogenicity & Guideline on immunogenicity assessment of biotechnology-derived therapeutic proteins ${ }^{35}$ \\
\hline \multicolumn{2}{|c|}{ Product specific - Annexes non-clinical and clinical } \\
\hline \multicolumn{2}{|c|}{ Guidance on similar medicinal products containing recombinant erythropoietins ${ }^{36}$} \\
\hline \multicolumn{2}{|c|}{ Guidance on similar medicinal products containing somatropin ${ }^{37}$} \\
\hline \multicolumn{2}{|c|}{ Guidance on similar medicinal products containing recombinant granulocyte-colony stimulating factor ${ }^{38}$} \\
\hline \multicolumn{2}{|c|}{ Guidance on similar medicinal products containing recombinant human insulin ${ }^{39}$} \\
\hline \multicolumn{2}{|c|}{ Non-clinical and clinical development of similar medicinal products containing recombinant interferon alpha ${ }^{40}$} \\
\hline Guideline on non-clinica & ent of similar biological medicinal products containing low-molecular-weight heparins ${ }^{41}$ \\
\hline
\end{tabular}

principles as well as economic considerations, and will have a significant positive therapeutic impact for millions of patients living with life-threatening and chronic diseases.

\section{Quality, safety, and efficacy}

The quality, safety, and efficacy of a biosimilar product must be approved by the relevant regulatory body before marketing approval can be gained, which requires an appropriate comparability exercise. The EMEA requires comparison of the biosimilar product with the innovator product to determine absence of any detectable differences. The quality comparison between the biosimilar and the innovator product is crucial, because the quality of a protein product affects its safety and efficacy. It is known that biopharmaceutical manufacturing is a multistep process, involving cloning of the appropriate genetic sequence into a carefully selected expression vector, selection of a suitable cell expression system, and scale-up and purification, up to formulation of the end product ${ }^{18}$ (Figure 1). Towards the particular manufacturing process used, biopharmaceuticals exhibited great sensitivity, and variation in product quality was commonly observed, even when the exact same process of manufacturing was used. The challenge then remains to assess and quantify these differences, and determine whether the new product is as safe and efficacious as the innovator product. Further, variability of source material has also been known to affect product quality. Thus the product is affected both by the host cell and the processing steps that follow. In addition, protein molecules can be degraded during processing steps and impurities created in these steps can contribute to decreased potency and/ or increased immunogenicity. ${ }^{45}$ With the large number of quality attributes (Table 4), acquiring a complete knowledge of the impact of each of the attributes on clinical safety and efficacy is not feasible. ${ }^{46}$ However, the recent guidelines of the International Conference on Harmonization Q8 on pharmaceutical development, ${ }^{47}$ and the roll-out of the Quality by Design ${ }^{48}$ and Process Analytical Technology ${ }^{49}$ initiatives from the FDA have improved understanding of the impact of manufacturing processes and their starting materials, on product quality.

Biochemical characterization of the protein product requires sophisticated analytical tools to detect the possibilities of changes to the product. Further, the characterization of the product requires a variety of methods for different attributes or, alternatively, with orthogonal methods for the characterization of a given attribute, thus developing a comprehensive finger-printing of a protein product. ${ }^{50,51}$ However, key challenges remain that continue to require attention, primarily because of the high complexity of the products, processes, and raw materials that are part of the manufacturing of biotechnology products.

Virtually all therapeutic proteins induce some level of antibody response. The immune reaction can vary from lowtiter, low-affinity, and transient IgM antibodies to a high-titer, high-affinity IgG response, with consequences ranging from none to severe or life threatening. Many factors determine the appearance of immunogenicity, including patient characteristics and disease state, and the therapy itself influences the generation of an immune response. Product-related factors such as the molecule design, the expression system, post-translational modifications, impurities, contaminants, formulation and excipients, container, closure, as well as degradation products are all implicated. ${ }^{52}$

It is fundamental to conduct pre-clinical and clinical studies to understand the safety, efficacy, and quality of both the innovator product and biosimilar medicines. Preclinical studies are not yet capable of assessing the clinically 
Table 4 Methods for QSE assessment of biosimilars

\begin{tabular}{ll}
\hline Attributes & Methods \\
\hline $\begin{array}{l}\text { Primary sequence (peptide map and amino acid } \\
\text { sequence analysis), immunogenicity (immunoassay) } \\
\text { other identity indicators }\end{array}$ & IE, HPLC, gel electrophoresis \\
Potency & \\
Conformation & Cell-based bioassay, gene expression bioassay, ADCC, CDC \\
Glycosylation & Near/far UV circular dichroism spectroscopy, Fourier transform infrared \\
& spectroscopy, X ray crystallography and differential scanning calorimetry \\
Phosphorylation & Monosaccharide composition analysis, oligosaccharide profile, CE, LC-MS, \\
Truncation & MS/MS, ESI, MALDI-TOF \\
Glycation & Peptide mapping with MS \\
Pegylation & SE-HPLC, gel electrophoresis, AUC, peptide mapping with MS, RP HPLC \\
Aggregation & Peptide mapping with (MS, HPLC), methylation, isomerization (RP HPLC) \\
Oxidation & HPLC, CE \\
Deamidation & SE-HPLC, gel electrophoresis, Light scattering and AUC \\
& Peptide mapping with MS \\
Host cell proteins & Capillary IEF, peptide mapping with MS, and CEX-HPLC, C-terminal lysine \\
Binding & (capillary IEF, peptide mapping with MS, and CEX-HPLC), misfolds (RP-HPLC) \\
Biological activity & ELISA, DNA, endotoxin (Limulus amebocyte lysate assay) \\
\hline
\end{tabular}

Abbreviations: IE, ion exchange; HPLC, high performance liquid chromatography; ADCC, antibody-dependent cell-mediated cytotoxicity; CDC, complement-dependent cytotoxicity; CE, capillary electrophoresis; LC-MS, liquid chromatography-mass spectroscopy; MS/MS, tandem mass spectrometry; ESI, electrospray ionization; MALDI-TOF, matrix-assisted laser desorption/ionization time of flight MS; AUC, analytical ultracentrifugation; CEX, cation exchange; IEF, isoelectric focusing; SE, size exclusion; RP-HPLC, reverse phase HPLC; ELISA, enzyme-linked immunosorbent assay; QSE, quality safety and efficacy.

relevant immunogenicity potential of these product-related factors. Understandably, most of the focus has been on assessing immunogenicity of protein products by non-clinical studies. ${ }^{53-55}$ Despite advances in biochemical characterization and other non-clinical methods for assessment of immunogenicity, the unpredictability of the human immune system still necessitates detailed safety assessments, which will rely heavily on clinical trials. This is why clinical experience, through clinical trials and extensive pharmacovigilance programs, remains the most reliable way to assess immunogenicity. ${ }^{56-58}$

The best example of unexpected things happening with protein drugs that have been well characterized is Hospira's biosimilar epoetin zeta $\left(\right.$ Retacrit $\left.^{\circledR}\right)$, which was approved by EMEA. Eprex ${ }^{\circledR}$ (Amgen/Johnson \& Johnson) is synthetic erythropoietin (epoetin alpha) and is used to replace the erythropoietin that is lacking in people who cannot make enough, usually because their kidneys are not working properly. Epoetin alpha is also used to treat people with cancer who develop anemia because of chemotherapy treatment. Although preapproval physicochemical, in vivo, and animal testing showed that it was biosimilar to its innovator product epoetin alpha (Eprex), it had lower potency in clinical trials. ${ }^{59}$ Accordingly, current analytical techniques are unable to assess immunogenicity and potency. This is evident from the Eprex case which showed that one protein can be different from another in ways that cannot be detected in the laboratory, but are seen only by the body's exquisitely sensitive immune system. If one change to a well-established complex manufacturing process, made by the manufacturer who has intimate knowledge of the process, can cause a problem with immunogenicity, surely the risk is even greater with an entirely new manufacturer and process - as with biosimilar. ${ }^{60}$

Recently launched efforts, such as the EMEA concept paper on immunogenicity assessment of monoclonal antibodies intended for in vivo clinical use, are expected to provide further clarity on this topic. ${ }^{61}$ Further, when the Committee for Medicinal Products for Human Use (CHMP)/EMEA evaluations to date were examined, any difference in host cell expression system, purity, and formulation appears acceptable if the clinical data show no negative effect. ${ }^{62}$ Besides safety of an innovator product, evidence suggested that efficacy can also be a concern. The products were characterized for similarity in the types of glycoforms present, the relative degree of unfolding, in vitro potency, presence of covalent aggregates, and presence of cleavage aggregates. The biochemical discrepancies between the different copy products were most likely caused by the differences in the cell lines and the manufacturing process. ${ }^{63}$

\section{EMEA status of biosimilars: approval or rejection}

In the EU, a total of 14 brand name biosimilars (based on 4 reference products) from nine companies were approved 
since the pathway for regulatory approval of biosimilars was established (Table 5). ${ }^{64}$ In 2006, the EMEA rejected an application for approval of a biosimilar interferon product due to concerns about product characterization, manufacturing, and quality control. ${ }^{65}$ Also, in December, 2007, Marvel Life Sciences officially notified CHMP that it wished to withdraw its applications for marketing authorizations for a range of biosimilar insulins, based on the decision of the CHMP not to grant an extension to the timeframe given to them to respond to a list of questions. ${ }^{66}$ Concerns raised by the CHMP over biosimilarity, drug product, and substance, and both clinical and non-clinical aspects, highlights that the approval pathway for biosimilars is not straightforward, with products requiring assessment on a case-by-case basis. ${ }^{67}$

EMEA provides information on the approval process for human medicines (the European Public Assessment Report, EPAR), including a scientific discussion on the clinical data submitted for approval. Generally, the EPARs for biosimilars have stated that the biosimilar received approval because it was shown to have a quality, safety, and efficacy profile comparable to the innovator product. ${ }^{68-75}$

\section{Pharmacovigilance of biosimilars}

Pharmacovigilance is particularly concerned with adverse drug reactions. Recently, pharmacovigilance concerns have been widened to include innovator product and biosimilars. Clinical trials and post-authorization pharmacovigilance

Table 5 Biosimilars approved or rejected timeline

\begin{tabular}{lll}
\hline Biosimilar & Reference & $\begin{array}{l}\text { Approval/Rejection } \\
\text { year }\end{array}$ \\
\hline Omnitrope & Somatropin & $2006^{*}$ \\
Valtropin & Somatropin & $2006^{*}$ \\
Binocrit & Epoetin alpha & $2007^{*}$ \\
Epoetin alpha & Epoetin alpha & $2007^{*}$ \\
Hexal & Epoetin alpha & $2007^{*}$ \\
Abseamed & Epoetin zeta & $2007^{*}$ \\
Silapo & Epoetin zeta & $2007^{*}$ \\
Retacrit & Filgrastim & $2008^{*}$ \\
Filgrastim & & \\
Ratiopharm & Filgrastim & $2008^{*}$ \\
Ratiograstim & Filgrastim & $2008^{*}$ \\
Biograstim & Filgrastim & $2008^{*}$ \\
Tevagrastim & Filgrastim & $2009^{*}$ \\
Filgrastim hexal & Filgrastim & $2009^{*}$ \\
Zarzio & Filgrastim & $2010^{*}$ \\
Nivestim & Roferon-A & $2006^{* *}$ \\
Alpheon & Humulin & $2007^{* *}$ \\
\hline Human insulin &
\end{tabular}

Notes: *Approved, **Rejected are considered essential to guarantee the product's safety and efficacy over time. Pharmacovigilance, as part of a comprehensive risk management programme, will need to include regular testing for consistent manufacturing of the drug. ${ }^{76}$ The most critical safety concern relating to biopharmaceuticals (including biosimilars) is immunogenicity. ${ }^{77,78}$ Minimization of immunogenicity has to begin at the molecule design stage by reducing or eliminating antigenic epitopes and building in favorable physical and chemical properties. ${ }^{79}$ Pharmacovigilance is important in the biosimilars market because of the limited ability to predict clinical consequences of seemingly innocuous changes in the manufacturing process and the scientific information gap. ${ }^{56}$ The Eprex example also underscores other critical points. First, careful post-market monitoring of the safety of a biologic, whether innovative or biosimilar, is extremely important. Increased pharmacovigilance with biopharmaceuticals was highlighted with the Eprex (epoetin alfa) pure red cell aplasia issue. CHMP guidelines emphasize the need for particular attention to pharmacovigilance, especially to detect rare but serious side effects. ${ }^{56}$ Pharmacovigilance systems should differentiate between innovator product and biosimilar products, so that effects of biosimilars are not lost in the back-ground of reports on innovator products. ${ }^{80}$ Further, the risk management plan for biosimilars should focus on increasing pharmacovigilance measures, identify immunogenicity risk, and implement special post-marketing surveillance. Although International Nonproprietary Names (INNs) served as a useful tool in worldwide pharmacovigilance, for biological products, they should not be relied upon as the only means of product identification. In addition, biological products should always be commercialized with a brand name or the INN plus the manufacturer's name. ${ }^{81}$

To improve patient safety through enhanced pharmacovigilance, Novartis supports the recent initiative in the EU to review and improve the pharmacovigilance system of medicinal products in Europe. In addition, valid pharmacovigilance procedures should be mandatory for all products of a certain category (eg, biopharmaceutical) and not depend on whether the relevant brand is an innovator product or a biosimilar product. ${ }^{82}$

Biologicals carry specific risks. Safety problems, for example infliximab and the risk for tuberculosis, have been identified via spontaneous reports of suspected adverse drug reactions (ADRs). Data obtained from the ADR database (VigiBase), maintained by the WHO Collaborating Centre for International Drug Monitoring, indicated that biologicals 
have a different safety profile compared with all other drugs in the database and, within the group of biologicals, differences exist between mechanistic classes. In addition, because not all adverse reactions can be predicted or detected during development, spontaneous reporting remains an important tool for the early detection of signals. ${ }^{83}$ Further, pharmacovigilance plans developed and implemented by manufacturers are frequently part of the post-approval commitments to regulatory agencies to provide follow-up safety assessments. It was years of pharmacovigilance that allowed physicians to determine that the problem with Eprex occurred possibly because the switch to polysorbate 80 caused the drug to react to the rubber stopper used in vials. Pharmacovigilance of biosimilars from a regulatory point of view has been reported. ${ }^{84}$

\section{Commercial opportunities}

Biosimilar development is a landmine of complexities with respect to regulatory, manufacturing, and marketing aspects, making it one of the most expensive development propositions in the pharmaceutical industry. Like generic pharmaceuticals, biosimilars enter the market with the aim of reducing healthcare cost, but entry to the biosimilar market carries higher costs, greater risks, and more time and expertise in relation to the clinical development of these products. Furthermore, the marketing and launch of biosimilars requires a different strategy than small-molecule generics. The considerable costs to obtain FDA approval, and the substantial costs to develop manufacturing capacity, will limit the number of biosimilar competitors. In this scenario, very few biosimilar manufacturers are likely to attempt entry for a given innovator product and are unlikely to introduce their drugs only at discounts normally in the range of $10 \%$ to $30 \%$ of the innovator product price. Further, the lack of automatic substitution between a biosimilar and an innovator product will slow the rate at which a biosimilar can obtain market share. Therefore, it is easy to see that currently, the type and amount of resources required for biosimilar development can create high barriers of entry, not just for small to mid-sized companies, but even for the larger, well-established generics players and global biopharmaceutical companies. ${ }^{85-87}$ Gaining market share for a biosimilar could be challenging when there is no added benefit over the innovator and insignificant cost savings. The price decrease can be achieved when multiple biosimilars are introduced to the market. ${ }^{88}$

On the other hand, if a substantial price decrease is not viable for a biosimilar, a better strategy seems to be to develop a biosimilar as a new product. It would benefit the sponsor to use a scientific rationale and its own nonclinical and clinical testing, most of which will be required anyway, to develop its product as a unique innovator product, and gain the benefit of extended market exclusivity. ${ }^{89}$

\section{Biosimilars in clinical practice}

Despite the comparability of biosimilars to the innovator product, clinicians and health care workers should be aware of some of the issues that have emerged during the development and approval of these products, which highlight the challenges of biosimilars. ${ }^{65}$ The use of biosimilars is essentially a change in clinical management. ${ }^{90}$ By taking a leading role in educating patients and medical professionals about the risks and benefits of biosimilars, the Pan American and Health Education Foundation is actively involved in improving patient safety. ${ }^{91}$

\section{The role of nurses in the use of biosimilars}

Nurses are used to administering generic versions of chemically synthesized drugs which have identical therapeutic properties, and cause the same adverse events as, their branded counterparts. Biosimilars, however, are not identical to the innovator biopharmaceutical products they seek to replicate. The lack of nursing awareness and education about biosimilars can lead to medication errors, adverse events, or a delay in desired therapeutic gain for the patient. ${ }^{92}$

The complex nature of innovator products and biosimilar biopharmaceuticals requires that nurses are better informed about their differences (to the extent they exist), use, and effects. Experts are of the opinion that responsibility must be placed on manufacturers, professional bodies, and prescribers to ensure that the nursing profession has continued access to updated information on current and emerging biopharmaceutical products. In addition, safe use of such products should be embedded in education, policies, and procedures. Furthermore, the challenges and the need for increased awareness of biosimilars in nursing and clinical practice have been reported. ${ }^{93}$ In addition to education, it is essential that nurses take meticulous records when administering biopharmaceuticals.

Challenges facing biosimilars when educational curriculum or materials are designed, are adequate advice to patients and colleagues, assessing medication substitution, and assessing and evaluating patients, thus requiring nurses to be proactive in being well informed about the biopharmaceuticals that are available, and to gain knowledge and training that is current and evidence-based..$^{94}$ 


\section{The role of hospital pharmacists}

It is of utmost importance that the hospital pharmacist is aware that the innovator products and biosimilars are not interchangeable, because patients must be carefully monitored if their treatment is changed between products. Moreover, patient welfare is foremost and for pharmacists, the knowledge that biosimilars are not generics, and the possible implications for clinical outcomes when products are switched, will help ensure patient safety. ${ }^{95}$

Additionally, biosimilars are deemed to contain a new active ingredient, whereas interchangeable products are not. The Eprex example also provides a rationale for not considering a biosimilar to be interchangeable with an innovative product. FDA has stated that it has not determined how interchangeability can be established for complex proteins. ${ }^{96,97}$

Systematic checklists have been proposed for the evaluation of biopharmaceuticals coming on to the market, which have provided additional reassurance for the pharmacist. For example, the Pharmacy Checklist for Retacrit (epoetin zeta) provides information on manufacturing, protein and product formulation, batch consistency, supply reliability, good handling practice, clinical efficacy, and clinical safety and tolerability. ${ }^{98}$ The successful introduction of EU biosimilar erythropoietins, such as Retacrit gives hospital pharmacists the opportunity to reduce costs and improve the treatment of patients with anemia.

\section{Conclusions and perspectives}

The problems of biosimilars are in active debate around the globe. A critical evaluation is needed for more efficient, cost effective widespread availability of biosimilars. Because biosimilar products are very complex molecules, factors such as the robustness of the manufacturing process, structural similarity to the parent molecule, level of understanding of the mechanism of action, quality of pharmacodynamic assays utilized, demonstrated comparability in pharmacokinetics and immunogenicity, quantity and quality of clinical data, and the innovator's experience with the parent product needs to be considered critically before marketing approval of biosimilars can be granted. The decision on interchangeability is still pending and under such a designation, the substitution of the biosimilar for the innovator product without involving the prescribing physician is not appropriate. In this respect, physician awareness of potential differences between biopharmaceuticals and biosimilars and the impact on safety and efficacy is vital for patient safety. Clinicians require comprehensive information on biosimilars, and biopharmaceuticals in general, to make knowledgeable treatment decisions. In addition, pharmacovigilance will be essential to track down any safety and efficacy problems that may arise from the use of biosimilars. Further, the regulations for the naming and the labeling of biosimilar products should be the responsibility of a single authorized body and should be globally acceptable. Although biosimilars have begun to enter the global market, the biosimilar manufacturers' long-term capability to manufacture a consistent product still remains to be proven. At present, even though European legislation is in place to assess and grant marketing approval for biosimilars, the EMEA guidelines only provide a road map and leave challenging areas still to be explored and monitored. Approvals of biosimilar products should continue to be dealt with on a case-by-case basis.

\section{Disclosure}

The authors declare no conflicts of interest.

\section{References}

1. Leader B, Baca QJ, Golan DE. Protein therapeutics: a summary and pharmacological classification. Nat Reviews Drug Discov. 2008;7: 21-39

2. Genentech Inc. Corporate Chronology. 1982. http://www.gene.com/ gene/about/corporate/history/timeline.html.

3. Global Biopharmaceutical Market Report (2010-2015) IMARC October 29, 2010:234 Pages. Pub ID: IMRC2849563.

4. http://www.icis.com/Articles/2010/02/15/9333235/follobw-on-biologicspresent-opportunity-to-big-pharma.html.

5. Roger SD, Goldsmith D. Biosimilars: it's not as simple as cost alone. J Clin Pharm Ther. 2008;33:459-464.

6. Avidor Y, Mabjeesh NJ, Matzkin H. Biotechnology and drug discovery: from bench to bedside. South Med J. 2003;96:1174-1186.

7. IMS Health. IMS Webinar: Biologics. 2009. http://www.imshealth.com/ portal/site/imshealth/menuitem.a675781325ce246f7cf6bc429418c22a /?vgnextoid=a0c22e9b65802210VgnVCM100000ed152ca2RCRD\&v gnextfmt=default.

8. BIO. Biotechnology Industry Facts. 2009. http://bio.org/speeches/ pubs/er/statistics.asp.

9. Hincal F. An introduction to safety issues in biosimilars/follow-on biopharmaceuticals. J Med CBR Def. 2009;7:1-18.

10. Ledford H. Biosimilar drugs poised to penetrate market. Nature. 2010; 468:18-19

11. Shaldon S. Biosimilars and biopharmaceuticals: what the nephrologist needs to know - a position paper by the ERA-EDTA Council. Nephrol Dial Transplant. 2009;24:1700-1701.

12. Covic A, Cannata-Andia J, Cancarini G, et al. Biosimilars and biopharmaceuticals: what the nephrologists need to know - a position paper by the ERA-EDTA Council. Nephrol Dial Transplant. 2008;23. 3731-3737.

13. De Groot AS, Scott DW. Immunogenicity of protein therapeutics. Trends Immunol. 2007;28:482-490.

14. Marshall SA, Lazar GA, Chirino AJ, Desjarlais JR. Rational design and engineering of therapeutic proteins. Drug Discov Today. 2003;8: 212-221.

15. Revers L, Furczon E. An introduction to biologics and biosimilars Part II: subsequent entry biologics: biosame or biodifferent? Can Pharmacists J (CPJ/RPC). 2010;143:184-191.

16. Crommelin DJA, Storm G, Verrijk R, Leede L, Jiskoot W, Hennink WE. Shifting paradigms: biopharmaceuticals versus low molecular weight drugs. Intern J Pharmaceut. 2003;266:3-16. 
17. Revers L, Furczon E. An introduction to biologics and biosimilars. Part I: biologics: what are they and where do they come from? Can Pharmacists J CPJ/RPC. 2010;143:134-139.

18. Goldsmith D, Kuhlmann M, Covic A. Through the looking glass: the protein science of biosimilars. Clin Exp Nephrol. 2007;11: 191-195.

19. Crommelin DJ, Bermejo T, Bissig M, et al. Pharmaceutical evaluation of biosimilars: important differences from generic low-molecular-weight pharmaceuticals. Eur J Hosp Pharm Sci. 2005;11:11-17.

20. Sahoo N, Choudhury, K, Manchikanti P. Manufacturing of biodrugs: need for harmonization in regulatory standards. Biodrugs. 2009;23: 217-229.

21. Assessing the impact of a safe and equitable biosimilar policy in the United States: Hearing before the H. Comm. on energy and commerce, Subcomm. on health, 110th Cong. 8, 2007.

22. Toon S. The relevance of pharmacokinetics in the development of biotechnology products. Eur J Drug Meatabol Pharmacokinet. 1996;21: 93-103.

23. Dempster MA. Nonclinical safety evaluation of biotechnologically derived pharmaceuticals. Biotechnol Ann Rev. 2000;5:221-258.

24. Galluppi GR, Rogge MC, Roskos LK, Lesko LJ, Green MD, Feigal DW, et al. Integration of pharmacokinetic and pharmacodynamic studies in the discovery, development, and review of protein therapeutic agents: a conference report. Clin Pharmacol Ther. 2001;69:387-399.

25. Elmquist WF, Miller DW. The use of transgenic mice in pharmacokinetic and pharmacodynamic studies. J Pharmaceut Sci. 2000;90:422-435.

26. Schellekens H, Klinger E, Mühlebach S, Brin JF, Storm G, Crommelin DJ. The therapeutic equivalence of complex drugs. Regul Toxicol Pharmacol. 2010;59:176-183.

27. Rao SK. Pricing biologics: issues, strategic priorities and a conceptual model. J Commer Biotechnol. 2011;17:7-23.

28. Trusheim MR, Aitken ML, Berndt ER. Characterizing markets for biopharmaceutical innovations: Do biologics differ from small molecules? Forum for health economics and policy NBER Working Paper No. 16014, May 2010; JEL No. D21,I11,I18,L65. http://www.nber.org/papers/ w16014.pdf.

29. Roger SD. Biosimilars: how similar or dissimilar are they? Nephrology (Carlton). 2006;11:341-346.

30. Roger SD, Mikhail A. Biosimilars: opportunity or cause for concern? J Pharm Pharmaceut Sci. 2007;10:405-410.

31. Schellekens H. Follow-on biologics: challenges of the 'next generation'. Nephrol Dial Transplant. 2005;20:31-36.

32. EMEA, Guideline on similar medicinal products, CHMP/437/04, London, UK: European Medicines Agency, 2005. http://www.emea. europa.eu/pdfs/human/biosimilar/043704en.pdf.

33. Guideline on similar biological medicinal products containing biotechnology-derived proteins as active substance: quality issues. London, UK: European Medicines Agency, 2006. http://www.emea. europa.eu/pdfs/human/biosimilar/4934805en.pdf.

34. Guideline on similar biological medicinal products containing biotechnology-derived proteins as active substance: non-clinical and clinical issues. London, UK: European Medicines Agency. 2006. http://www. emea.europa.eu/pdfs/human/biosimilar/4283205en.pdf.

35. Guideline on immunogenicity assessment of biotechnology-derived therapeutic proteins. London, UK: European Medicines Agency, 2007. http://www.emea.europa.eu/pdfs/human/biosimilar/1432706enfin.pdf.

36. Annex to guideline on similar biological medicinal products containing biotechnology-derived proteins as active substance: non-clinical and clinical issues. Guidance on similar medicinal products containing recombinant erythropoietins. London, UK: European Medicines Agency, 2006. http://www.emea.europa.eu/pdfs/human/biosimilar/9452605en. pdf.

37. Annex to guideline on similar biological medicinal products containing biotechnology-derived proteins as active substance: non-clinical and clinical issues. Guidance on similar medicinal products containing somatropin. London, UK: European Medicines Agency, 2006. http:// www.emea.europa.eu/pdfs/human/biosimilar/9452805en.pdf.
38. Annex to guideline on similar biological medicinal products containing biotechnology-derived proteins as active substance: non-clinical and clinical issues. Guidance on similar medicinal products containing recombinant granulocyte-colony stimulating factor (G-CSF). London, UK: European Medicines Agency, 2006. http://www.emea.europa.eu/ pdfs/human/biosimilar/3132905en.pdf.

39. Annex to guideline on similar biological medicinal products containing biotechnology-derived proteins as active substance: non-clinical and clinical issues. Guidance on similar medicinal products containing recombinant human insulin. London, UK: European Medicines Agency, 2006. http:// www.emea.europa.eu/pdfs/human/biosimilar/3277505en.pdf.

40. Non-clinical and clinical development of similar medicinal products containing recombinant interferon alfa. London, UK: European Medicines Agency, 2009. http://www.emea.europa.eu/pdfs/human/ biosimilar/10204606enfin.pdf.

41. Guideline on non-clinical and clinical development of similar biological medicinal products containing low-molecular-weight-heparins. London, UK: European Medicines Agency, 2009. http://www.emea.europa.eu/ pdfs/human/biosimilar/11826407enfin.pdf.

42. Jelkmann W. Biosimilar epoetins and other "follow-on" biologics: update on the European experiences. Am J Hematol. 2010;85: 771-780.

43. US Food and Drug Administration. Omnitrope (somatropin) [rDNA origin]: questions and answers, 2006. www.fda.gov/cder/drug/infopage/ somatropin/qa.htm.

44. Health Canada. Information and submission requirements for subsequent entry biologics (SEBs) and related documents. 2010. www. hcsc.gc.ca/dhp-mps/brgtherap/applicdemande/guides/seb-pbu/noticeavis_seb-pbu_2010-eng.php.

45. Patro SY, Freund E, Chang BS. Protein formulation and fill-finish operations. Biotechnol Annu Rev. 2002;8:55-84.

46. Rathore AS. Follow-on protein products: scientific issues, developments and challenges. Trends Biotechnol. 2009;27:698-705.

47. Guidance for Industry: Q8 Pharmaceutical Development, US Department of Health and Human Service, Food and Drug Administration (FDA). May 2006. Q8 Annex Pharmaceutical Development, Step 3, November 2007.

48. Rathore AS, Winkle H. Quality by design for biopharmaceuticals. Nat Biotechnol. 2009;27:26-34.

49. PAT Guidance for Industry - A Framework for innovative pharmaceutical development, manufacturing and quality assurance. September 2004. http://www.fda.gov/downloads/Drugs/guidancecomplianceregu latoryinformation/guidances/ucm070305.pdf.

50. Chirino AJ, Mire-Sluis A. Characterizing biological products and assessing comparability following manufacturing changes. Nat Biotechnol. 2006;22:1383-1391.

51. Kozlowski S, Swann P. Current and future issues in the manufacturing and development of monoclonal antibodies. Adv Drug Deliv Rev. 2006;58:707-722.

52. Sharma B. Immunogenicity of therapeutic proteins. Part 3: impact of manufacturing changes. Biotechnol Adv. 2007;25:325-331.

53. Swann PG, Tolnay M, Muthukkumar S, Shapiro MA, Rellahan BL, Clouse KA. Considerations for the development of therapeutic monoclonal antibodies. Curr Opin Immunol. 2008;20:493-499.

54. De Groot AS, Scott DW. Immunogenicity of protein therapeutics. Trends Immunol. 2007;28:482-490.

55. De Groot AS, Moise L. Prediction of immunogenicity: state of the art. Curr Opin Drug Discov Dev. 2007;10:332-340.

56. Zuniga L, Calvo B. Biosimilars: pharmacovigilance and risk management. Pharmacoedidemiology Drug Saf. 2010;19:661-669.

57. Thijs J Giezen, Sabine MJM, Straus A, Mantel-Teeuwisse AK. Pharmacovigilance of biosimilars from a regulatory point of view: is there a need for a specific approach? Int J Risk Saf Med. 2009;21: 53-58.

58. Pavlovic M, Girardin E, Kapetanovic L, Ho K, Trouvin JH. Similar biological medicinal products containing recombinant human growth hormone: European regulation. Horm Res. 2008;69:14-21. 
59. Schellekens H. Assessing the bioequivalence of biosimilars: the Retacrit case. Drug Discov Today. 2010;14:495-499.

60. http://www.bio.org/healthcare/followonbkg/PatientSafety.asp.

61. Committee for medical products for human use. Concept paper on immunogenicity assessment of monoclonal antibodies intended for in vivo clinical use. EMEA/CHMP/BMWP/114720/2009.

62. Schellekens H, Moors E. Clinical comparability and European biosimilar regulations. Nature Biotechnol. 2010;28:28-31.

63. Park SS, Park J, Ko J, et al. Biochemical assessment of erythropoietin products from Asia versus US Epoetin alfa manufactured by Amgen. J Pharmaceut Sci. 2009;98;1688-1699.

64. www.gabionline.net/Biosimilars/Research/Developing-biosimilarspotential-risks-and-challenges

65. Questions and answers on recommendation for refusal of marketing application for Alpheon. London, UK: European Medicines Agency, 2006. http://www.emea.europa.eu/pdfs/human/opinion/19089606en. pdf. Accessed March 29, 2010.

66. Questions and answers on the withdrawal of the marketing authorisation application for Insulin Human Rapid Marvel Insulin Human Long Marvel Insulin Human 30/70 Mix Marvel. London, UK, European Medicines Agency, 2008. http://www.ema.europa.eu/humandocs/PDFs/ EPAR/insulinhumanrapidmarvel/419308en.pdf. Accessed March 29, 2010.

67. Misra A. Are biosimilars really generics? Expert Opin Biol Ther. 2010; 10:489-494.

68. European Medicines Agency. Omnitrope: EPAR summary for the public 2007. http://www.emea.europa.eu/humandocs/PDFs/EPAR/ Omnitrope/060706en1.pdf. Accessed March 3, 2008.

69. European Medicines Agency. Valtropin: EPAR summary for the public 2006. http://www.emea.europa.eu/humandocs/PDFs/EPAR/ valtropin/H-602-en1.pdf. Accessed March 4, 2008.

70. European Medicines Agency. Retacrit: EPAR summary for the public 2008. http://www.emea.europa.eu/humandocs/PDFs/EPAR/retacrit/ H-872-en1.pdf. Accessed March 3, 2008.

71. European Medicines Agency. Silapo: EPAR summary for the public 2007. http://www.emea.europa.eu/humandocs/PDFs/EPAR/silapo/ H-760-en1.pdf. Accessed March 3, 2008.

72. European Medicines Agency. Epoetin alfa HEXAL: EPAR summary for the public 2007. http://www.emea.europa.eu/humandocs/PDFs/ EPAR/epoetinalfahexal/H-726-en1.pdf. Accessed March 3, 2008.

73. European Medicines Agency. Binocrit: EPAR summary for the public 2007. http://www.emea.europa.eu/humandocs/PDFs/EPAR/binocrit/ H-725-en1.pdf. Accessed March 3, 2008.

74. European Medicines Agency. Abseamed: EPAR summary for the public 2007. http://www.emea.europa.eu/humandocs/PDFs/EPAR/ abseamed/H-727-en1.pdf. Accessed March 3, 2008.

75. Schellekens H Biosimilar therapeutics - what do we need to consider? NDT Plus. 2009;2(Suppl 1):i27-i36.

76. Locatelli F, Roger S. Comparative testing and pharmacovigilance of biosimilars. Nephrol Dial Transplant. 2006;21(Suppl 5):v13-v16.

77. Nowicki M. Basic facts about biosimilars. Kidney Blood Press Res. 2007;30:267-272.
78. Roger SD, Mikhail A. Biosimilars: opportunity or cause for concern? J Pharm Sci. 2007;10:405-410.

79. Singh SK. Impact of product-related factors on immunogenicity of biotherapeutics. J Pharm Sci. 2011;100:354-387.

80. EudraLex. Volume 9A - Guidelines on pharmacovigilance for medicinal products for human use. In: The rules governing medicinal products in the European Union, 2007. http://ec.europa.eu. Accessed December 1, 2009.

81. Kramer I. Pharmacy and pharmacology of biosimilars. J Endocrinol Invest. 2008;31:479-488.

82. http://www.corporatecitizenship.novartis.com/downloads/businessconduct/Novartis_Perspective_Pharmacovigilance_for_Biosimilars. pdf.

83. Giezen TJ, Mantel-Teeuwisse AK, Meyboom RHB, Straus SMJM, Leufkens HGM, Egberts TCG. Mapping the safety profile of biologicals: a disproportionality analysis using the WHO adverse drug reaction database, VigiBase. Drug Saf. 2010;33:865-878.

84. Schellekens H, Lisman J, Bols T. Biosimilars in clinical practice the challenges for hospital pharmacists. EJHPP Practice. 2008;14: $32-33$.

85. Generic Pharmaceutical Association. Press release. February 1, 2010 www.gphaonline.org. Accessed February 4, 2010.

86. Federal Trade Commission. FTC releases report on Follow-on Biologic Drug Competition. June 10, 2009. www.ftc.gov/opa/2009/06/biologics. shtm. Accessed February 4, 2010.

87. http://www.incresearch.com/Resource/Foresight/Foresight_201010Biosimilars.pdf.

88. Promise of biosimilars tempered by complexity, caution. January 10 , 2011; http://www.hemonctoday.com/article.aspx?rid=79243.

89. http://www.amarexcro.com/articles/docs/RAPS_Focus_Biosimilars_ Apr2010.pdf. Regulatory Focus, April 2010:21-26.

90. Mellstedt H, Niederwieser D, Ludwig H. The challenge of biosimilars. Ann Omol. 2008;19:411-419.

91. Background on Biosimilars. http://www.pahef.org/en/news/ 2-news/228-pahef-hosts-two-workshops-in-mexico-to-educate-aboutsafety-of-biosimilars.html.

92. http://www.faqs.org/periodicals/201007/2127490141.html\#ixzz1 BpLJT0d6.

93. Salem T, Harvie B. Biosimilar medicines and their use: the nurse's role and responsibility. Renal Soc Aust J. 2010;6:76-80.

94. http://www.faqs.org/periodicals/201007/2127490141.html\#ixzz1 BpMDNCBM.

95. Schellekens H, Lisman J, Bols T. Biosimilars in clinical practice the challenges for hospital pharmacists. EJHPP Practice. 2008;14: 32-33.

96. http://www.fda.gov/Drugs/DevelopmentApprovalProcess/How DrugsareDevelopedandApproved/ApprovalApplications/Therapeutic BiologicApplications/Biosimilars/default.htm. November 2010.

97. Declerck PJ, Darendeliler F, Góth M, et al. Biosimilars: controversies as illustrated by rhGH. Curr Med Res Opin. 2010;26:1219-1229.

98. Hospira symp on assessing biosimilars. http://www.thepharmaletter. com/file/89334/hospira-symp-on-assessing-biosimilars.html.

Biosimilars

\section{Publish your work in this journal}

Biosimilars is an international, peer-reviewed, open access journal focusing on the manufacture, development and medicinal use of biopharmaceutical compounds considered similar to an innovator agent. Specific topics covered in the journal include: Regulatory issues and pathways; manufacturing processes; chemical composition and

structure; quality and purity; patent issues; bioequivalence and interchangeability; clinical efficacy data; patient perspectives. The manuscript management system is completely online and includes a very quick and fair peer-review system. Visit http://www.dovepress.com/ testimonials.php to read real quotes from published authors.

\section{Dovepress}

